\title{
C-C Motif Chemokine 21
}

National Cancer Institute

\section{Source}

National Cancer Institute. C-C Motif Chemokine 21. NCI Thesaurus. Code C20484.

C-C motif chemokine 21 (134 aa, $\sim 15 \mathrm{kDa}$ ) is encoded by the human CCL21 gene. This protein plays a role in both the negative regulation of hematopoiesis and leukocyte chemotaxis. 